\title{
Clinical impact of early bronchoscopy in mechanically ventilated patients with aspiration pneumonia
}

\author{
S Park ${ }^{1 *}$, Y-J Cho ${ }^{2}$, YJ Lee ${ }^{2}$ \\ From ESICM LIVES 2015 \\ Berlin, Germany. 3-7 October 2015
}

\section{Background}

A handful of studies have reported that the proper timing of bronchoscopy influences the clinical outcome in mechanically ventilated patients with aspiration pneumonia.

\section{Methods}

Mechanically ventilated patients with aspiration pneumonia who received bronchoscopy in a medical intensive care unit at tertiary hospital from March 2003 to December 2013 were retrospectively reviewed. By definition, patients who underwent bronchoscopy within 24 hours after intubation were categorized as the early bronchoscopy group. We compared demographics, clinical parameters, and outcomes, including mortality, between the two groups.

\section{Results}

182 patients were included. Compared to the late bronchoscopy group, the early bronchoscopy group $(\mathrm{n}=$ 93) showed no significant differences in demographic features, including acute physiology and chronic health evaluation II scores. The early bronchoscopy group showed significantly lower in-ICU mortality and 90-day mortality (in-ICU: $6.5 \%$ vs. $26.1 \%$; 90 -day: 10.8 vs. $33.0 \%$ ) regardless of the appropriateness of the initial empirical antibiotics. In addition, their sequential organ failure assessment score on day 7 tended to decrease more rapidly. The early timing of bronchoscopy was associated with a lower 90-day mortality in multivariate analysis (odds ratio: $0.415 ; 95 \%$ confidence interval 0.183-0.942).

TSheikh Khalifa Specialty Hospital, RAK, United Arab Emirates

Full list of author information is available at the end of the article

\section{Conclusions}

Early bronchoscopy could benefit the clinical outcomes of mechanically ventilated patients with aspiration pneumonia.

\section{Authors' details}

'Sheikh Khalifa Specialty Hospital, RAK, United Arab Emirates. ${ }^{2}$ Seoul National University Bundang Hospital, Division of Pulmonary and Critical Care

Medicine, Bundang, Korea, Republic of Korea.

Published: 1 October 2015

doi:10.1186/2197-425X-3-S1-A388

Cite this article as: Park et al:: Clinical impact of early bronchoscopy in mechanically ventilated patients with aspiration pneumonia. Intensive Care Medicine Experimental 2015 3(Suppl 1):A388.

\section{SpringerOpen $^{\odot}$}

(c) 2015 Park et al.; This is an Open Access article distributed under the terms of the Creative Commons Attribution License (http:// creativecommons.org/licenses/by/4.0), which permits unrestricted use, distribution, and reproduction in any medium, provided the original work is properly cited.

Submit your manuscript to a SpringerOpen ${ }^{\circ}$ journal and benefit from:

- Convenient online submission

Rigorous peer review

- Immediate publication on acceptance

- Open access: articles freely available online

- High visibility within the field

- Retaining the copyright to your article

Submit your next manuscript at $>$ springeropen.com 